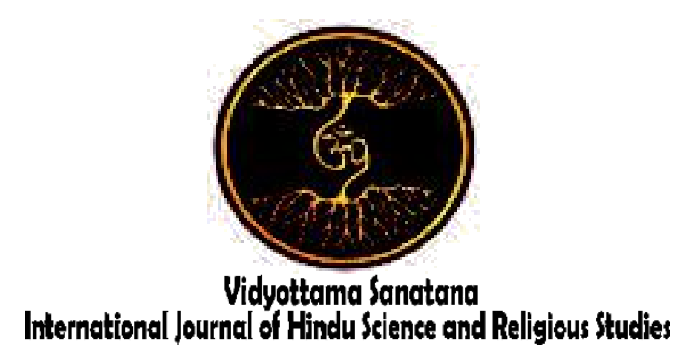

Vol. V No. 1 June 2021

\title{
THE EFFORTS OF HINDU RELIGIOUS EDUCATION TEACHERS IN THE IMPLEMENTATION OF ONLINE LEARNING IN THE NEW NORMAL ERA AT SMA NEGERI 2 KUALA KAPUAS
}

\author{
By \\ I Wayan Karya ${ }^{1}$, I Gede Dharman Gunawan ${ }^{2}$, I Wayan Salendra ${ }^{3}$, \\ Ni Putu Sri Pinatih ${ }^{4}$ \\ Institut Agama Hindu Negeri Tampung Penyang Palangka Raya \\ Email: ${ }^{1}$ wayankarya761@yahoo.co.id, ${ }^{2}$ dharman.gunawan@gmail.com, \\ 3salendraiwayan@gmail.com, ${ }^{4}$ putu.pinatih@gmail.com
}

Received: March 29, 2021

Accepted: Juni 30, 2021

Published: June 30, 2021

\begin{abstract}
The implementation of online learning is an effective solution for learning at home to break the chain of Covid-19 transmission. Physical distancing is also a consideration for choosing this type of learning. A good cooperation between teachers, students, parents and school is a determining factor in making online learning more effective. In connection with the problem previously described about the importance of the efforts of Hindu religious education teachers in the implementation of online learning in the current new normal era, those teachers are trying to utilize online media as an innovative Hindu religious education learning medium. Of course, the use of online media can foster an active, creative, effective and fun learning during the new normal era. Therefore the research team wanted to conduct a research that analyzed the problem of how Hindu religious education teachers made efforts in implementing online learning by using online media as a learning medium for Hindu religious education for students of SMA Negeri 2 Kuala Kapuas.
\end{abstract}

Keywords: The efforts of Hindu Religious Education Teachers, Online Learning

\section{INTRODUCTION}

Some local governments have decided to implement a policy of dismissing students and have started implementing online learning methods. Some policies have also been being implemented effectively in several provinces in Indonesia since March 2020 and followed by the other provinces. However in some regions, those policies cannot be implemented, especially in some schools because they are not ready yet for online learning. The main reason is by 
implementing online learning, they must prepare some learning media, such as smartphones, laptops and computers. The online learning system is a system without face-to-face interaction between teachers and students that must be done done online using the internet connection. Teachers must ensure that teaching and learning activities continue, even though students are at home. The only way to implement it is make the teachers be able to design learning media as an innovation by utilizing online media. The benefits of online learning are very beneficial, especially the flexibility in time management, if users, both educators and students, are able to manage online learning (Ariyana and Tristananda, 2020: 234).

Therefore teachers are required to be able to create and design online learning that is easy to apply, effective and appropriate for the students and the material by utilizing the appropriate online tools or media. Although online learning will provide wider opportunities to explore the material taught to the students, those teachers must be able to choose and limit the extent to which the material is covered, the appropriate application of the learning materials and methods used. The simplest thing that teachers can do is by using WhatsApp Group. This feature of WhatsApp application is suitable for beginners or students because it is very simple and easy to access. Meanwhile, online teachers who have more enthusiasm can improve their abilities by using various online learning applications.

According to Sudarsana (2020: 23), in teaching and learning interactions, Hindu religious education teachers will try to maximize their various skills and abilities, so that the students can achieve the expected goals. It means that the success of Hindu religious education teachers' efforts in conducting online learning is the ability of the teachers themselves to be more innovative in designing the materials, arranging the online class, choosing learning methods and using appropriate applications.
Creativity is the key to success for a teacher to be able to motivate students to stay enthusiastic about the online learning and it will not be a psychological burden. In addition, the success of online learning during this new normal era depends on the discipline of all parties. Therefore the schools need to make a scheme by compiling good management in regulating the online learning system. It can be done by creating a systematic, structured and simple schedule to facilitate communication between parents and schools so that their children who are studying at home can be monitored effectively.

Thus, the implementation of online learning is an effective solution to learning at home to break the chain of Covid-19 transmission and it also supports the implementation of physical distancing (maintaining a safe distance with other people). A good cooperation between teachers, students, parents and school is a determining factor in making online learning more effective. Related to the main focus of this research described previously about the importance of the efforts of Hindu religious education teachers in implementing online learning in this new normal era, it means that the teacher should try to maximize the various media as the best learning media for their students. These efforts certainly can foster active, creative, effective and fun learning activities during the new normal period. Therefore, It examines the problem of how the efforts of Hindu religious education teachers in conducting online learning by using online media as a learning medium for Hindu religious education towards the students of SMA Negeri 2 Kuala Kapuas.

\section{METHODS}

This study uses a qualitative method, where this method is carried out intensively, the researcher goes directly to the field, records what happens, carries out a reflective analysis of various documents found in the field, and makes detailed 
research reports (Sugiyono, 2019: 18). The research location is a place to study the research conducted. The research location is at SMA Negeri 2 Kuala Kapuas, Kapuas Regency. Based on preliminary observations made by the research team, Hindu religious education teachers before the Covid-19 pandemic in Hindu religious education learning used conventional learning methods interspersed with face to face discussions. However, at the time of the Covid-19 pandemic that hit, it required teachers and students to study from home. So the research team examined how the efforts of Hindu religious education teachers in the use of online media as online learning media in Hindu religious education learning at SMA Negeri 2 Kuala Kapuas. In collecting the data needed in research on the efforts of Hindu religious education teachers in the implementation of online learning at SMA Negeri 2 Kuala Kapuas in the new normal era are observation techniques, interview techniques, document studies techniques, and library studies.

\section{RESULTS AND DISCUSSIONS}

3.1 The Efforts of Hindu Religious Education Teachers in the Implementation of Online Learning at SMA Negeri 2 Kuala Kapuas

In the implementation of online learning, Hindu religious education teachers carry out several efforts, such as preparing, implementing and evaluating learning process. Preparation or planning is the initial stage that must be passed by them. At this stage the teachers prepare everything so that the learning process can run effectively and efficiently. The learning process is said to be effective if the delivery of learning materials is in accordance with the time allocation. In addition, a learning process can be considered effective if all learning materials can be understood by students. The learning strategy is an action plan (a series of activities) which includes the use of methods and the use of various resources in learning.
This means that the formulation of a new strategy until the work plan formulation process has not yet reached action.

According to Putria, et al., (2020: 862), as frontliners in education, teachers have the duty to teach, educate, train, guide, provide direction, assessment and evaluation in order to give moral and mental support to students. The teaching and learning process carried out by teachers and students is usually done at school or through direct interaction without any medium. However, the teacher's duties in the learning process mentioned earlier have changed in the last few months because of the Covid-19 outbreak that has spread around the world, including Indonesia.

Regarding the duties of teachers as the frontliners in education and online learning during the Covid-19 pandemic, Wati, the Hindu religious education teacher, in an interview stated that "the preparation is carried out in online learning by preparing good and interesting learning tools. Supporting facilities include computers, laptops and smartphones. Besides a textbook for Hindu religion and character is also prepared (interview on October $16^{\text {th }}, 2020$ )". In this case it is explained that the Hindu religious education teacher has made several efforts in preparing for online learning. There are some efforts that have been carried out such as preparing interesting learning tools and media. Supporting facilities like computers, laptops and smartphones are also necessary. In addition, those are also supported by the textbook. With careful preparation, the teachers show that they have strong will to create an effective online learning.

Furthermore, according to Asen, the Principal of SMA Negeri 2 Kuala Kapuas, explained that "it must be implemented by the school before the implementation of online learning, this is like a lesson for students. Therefore we need to ensure students can take advantage of, use and access online learning media implemented by the teacher. Furthermore, we also prepare 
tools that support online learning (interview on October $\left.16^{\text {th }}, 2020\right)$ ". Based on the results of the interview, it was found that the school as an educational institution plays an important role in preparing and supporting online learning. There are several efforts made by the school in preparing online learning, such as ensuring students can utilize, use and access online learning media implemented by teachers. Moreover, they also prepare devices that support online learning. According to Asen's opinion above, it is emphasized that the school is obliged to prepare several efforts before implementing online learning, so that it can be implemented and followed effectively by teachers and students.

At the implementation stage, teaching and learning activities are based on the teaching preparation made by the teachers. The distribution of learning materials is adjusted to the order that has been programmed systematically at the preparation stage. The implementation of learning process is a process that is arranged according to certain steps so that the implementation achieves the expected results (Nana Sudjana, 2010: 136). According to Syaiful Bahri and Aswan Zain (2010: 1), the implementation of learning process is an activity that has educational values and the interaction between teachers and students is coloured by those values. Educative interactions have educational values because the implementation of learning process is directed to achieve certain goals that have been formulated before the implementation of learning process begins.

Related to the implementation of learning process, according to Wati, the Hindu religious education teacher, stated that "online learning is a direct (physical) non-face-to-face (physical) learning system between teachers and students, but it is done online using an internet network. In any way, the teaching and learning process must be done and use internet network. If it is done patiently and sincerely, it will certainly produce good results, while maintaining everyone's health by following health protocols and appeals from the government (interview on October $16^{\text {th }}, 2020$ ). Based on the opinion of the informants above, an understanding can be drawn that online learning is a learning system without faceto-face interaction (physically) between teachers and students, but it is done online using the internet network. In addition, the implementation of this type of learning process is to achieve certain goals that have been formulated by the teachers.

Based on the result of interview about the efforts to implement online learning on October $17^{\text {th }} 2020$, Misnarupa stated that "the process of implementing online learning at SMA Negeri 2 Kuala Kapuas runs well and smoothly. All subject teachers carry out the learning process according to the learning schedule through the Zoom Meeting, WA, Google Classroom, etc." Furthermore, according to Risma Hutahaean's opinion, "in the online learning process the teacher tries to motivate students to be more enthusiastic in learning by continuously monitoring student attendance in learning process. Motivate students to complete assignments and correct their work immediately (interview on October $17^{\text {th }}$ 2020). "In brief, the results of the interviews of the two informants above shows that the online learning implementation process that has been running at SMA Negeri 2 Kuala Kapuas is going well and smoothly. All subject teachers carry out the learning process according to the learning schedule through some online applications. In addition, in the online learning process the teacher tries to motivate students to be more enthusiastic in learning by continuously monitoring student attendance in learning process. The efforts made in implementing online learning are surely adjusted to the learning objectives set by the teachers.

Furthermore, Wati, a Hindu religious education teacher (interview on October $\left.16^{\text {th }}, 2020\right)$ stated that "using internet-based interactive methods such as WA, classrooms 
and Zoom. The learning media used are visual media, audio and instructional videos. The materials used are the textbooks of Hindu religious education and character, the Veda, Panaturan Book and Kandayu book". According to the teacher's explanation above, , it can be said that the efforts of Hindu religious education teachers in the implementation of online learning use internet-based interactive methods such as WA, Google Classroom and Zoom. There are some media used by the teachers such as visual media, audio and instructional videos. The learning process is also supported by the textbooks of Hindu religious education textbooks and character, as well as the Veda and Panaturan scriptures.

Furthermore, in the process of evaluation of online learning, Hindu religious education teacher always try to know the students' understanding of the learning materials and determine the effectiveness and efficiency of the online learning that has been implemented. To find out whether students have mastered the material being taught, it is necessary to hold a post-test at the end of the learning process. The forms and types of tests used can vary, but they are still guided by the learning objectives that have been set. Forms of evaluation of students can be in the form of evaluation that students have completed a given set of programs, such as written tests, oral tests, multiple choices, true-false tests and performance tests.

Related to the explanation above, some efforts have been made by Hindu religious education teachers. It is also supported by Wati (interview on October $\left.16^{\text {th }}, 2020\right)$ who stated that "giving assignments in the form of questions is a way to evaluate the online learning process at this time, but some adjustments need to be made, for example by giving brief and clear questions so that students can understand them easily." From the statement above, it can be concluded that Hindu religious education teachers have made efforts to evaluate the implementation of online learning. One way of evaluating online learning is by giving assignments in the form of questions to students.

In line with the above opinion, Misnarupa stated that "The teachers monitor the attendance and activeness of students in online learning. They also provide assignments in form of essay and multiple choice (written form). The teachers motivate and encourage students to learn better. They always identify the problems faced by students in online learning and coordinate with other parties like principal, homeroom teacher, counseling teachers, staff and the parents (interview on October $17^{\text {th }}, 2020$ )." In brief, the efforts have been made to evaluate the implementation of online learning at SMA Negeri 2 Kuala Kapuas. In the closing activity which is the final part of the implementation of learning process, the teacher and students both individually and in groups must reflect so that they can evaluate all series of learning activities or learning activities along with the results obtained and then jointly find direct or indirect benefits from the learning results that have been taking place. The teacher provides feedback on the learning process and results. The teacher carries out follow-up activities in the form of assignments, both individual and group assignments. The teacher then must also provide information about the lesson plan for the next meeting.

\subsection{The Influential Factors of Online Learning at SMA Negeri 2 Kuala Kapuas} Online learning has created extraordinary euphoria in which learning process previously only relied on face-toface interaction. Distance and time was also limited. During this pandemic, it starts to transform into online in which those limitations will no longer happen. The rapid expansion on the development of internet as a potential course delivery platform, combined with the interests in lifelong learning and limited budgets, has created a significant incentive for universities to develop online programs. Then the 
technology is now available and relatively easy to use. Universities that are not ready for it will be left behind in this globalization era and technological development.

According to Pangondian, et al. (2019:58), in order to make online learning successful, the key is effectiveness, based on previous studies showing that there are 3 things that affects online learning, namely technology, teacher characteristics and student characteristics. Related to term technology, especially network settings that should allow for synchronization and asynchronization exchanges, students should have easy access and the network should take the minimum time to exchange documents. Then the characteristics of the teacher that plays a central role in the effectiveness of online learning,

It can be said that technological instructions made by the teacher is more important than the technology itself because it will affect the learning process directly such as the number of the students who attend the meeting. It also makes positive atmosphere in learning process when the teachers present the material so that the learning process will produce more positive outcomes. In conventional learning environments, students tend to be isolated because they do not have a special environment to interact with the teacher. In addition, the students who do not have basic skills and high self-discipline can do better learning with conventional methods, while students who are smart, have high-discipline and self-confidence will be able to do online learning methods.

According to Wati's opinion, Hindu religious education teacher, "the supporting factors includes adequate facilities, a conducive situation, a smooth internet network and it is guaranteed that they have sufficient quotas (interview on October $16^{\text {th }}$, 2020). Based on this opinion, it is known that the supporting factors are that the existence of adequate facilities, a conducive situation, a smooth internet network, and a sufficient quota that greatly affect the smooth implementation of online learning at SMA Negeri 2 Kuala Kapuas.

In line with the opinion of the previous informant above, $\mathrm{Ni}$ Luh Evariyanti further stated that "in my opinion, the factors that support online learning are the presence of a laptop or smartphone, support and enthusiasm both from teachers and parents, as well as interesting materials for online learning. Besides, the condition of the house should be safe and quite conducive. Having a personal cellphone is also important to make a comfortable online learning (interview on October $\left.23^{\text {rd }}, 2020\right)$. From those statement, it can be interpreted that the supporting factors during online learning are the presence of a laptop or smartphone, support and enthusiasm from teachers and parents, as well as interesting material. In addition, a condusive atmosphere of the house and having a personal smartphone will make the students comfortable when studying online. In other words all supporting factors are very important in the implementation of online learning for teachers and students of SMA Negeri 2 Kuala Kapuas.

In this new normal era, online learning has become commonplace in the teaching and learning process. Of course, there are several things that are hindering factors in online learning. One of them is that not all teachers are technology literate people. It means that there are still many teachers who are not as proficient in using technology as teachers who were born in or even under 1980. However they must always be ready because the world of education will certainly change day by day. In fact, Many teachers do not have devices because the economic factors as well as the students who are not from upper-class family.

According to Lailatussaadah, et al., (2020: 46), there are three factors inhibiting the implementation of online learning. Those factors are the inability to master technology, the internet connection, implementation time and commitment to the 
instructor. These factors become obstacles for teachers, especially in mastering technology, while the purpose of using it in online learning is to make the teachers more independent. Limited internet network, where online learning definitely requires an internet network, not everyone subscribes to internet service at home. There are still many people who still take advantage of cellular networks which are sometimes unstable. It could be because of the geographic location that is far from internet coverage and it could also be due to the weather. The most important issue is the limited budgetary costs. An internet network is very much necessary and must be available in online learning, but when the online learning system uses the internet network or the purchase of data quotas soars up. This is also one of the factors hindering the implementation of the effectiveness of online learning because many teachers and students' parents have not been able to set aside a budget to buy packages or quotas.

Furthermore $\mathrm{Ni}$ Luh Evariyanti (interview on October $23^{\text {rd }}, 2020$ ) added that "the factor that hinders during online learning is an unstable network during the learning time. The network is unstable, students do not always have enough quotas to take part in the online learning process." In addition, according to Dwi Ningrat's opinion, "the biggest problem is the existence of an unstable network, limited internet quota and a lack of understanding of learning materials from students." In summary, it can be concluded that there are factors that hinder participating in online learning such as an unstable network during the learning time. The network is sometimes unstable and it makes the students do not always have sufficient quotas to take part in the online learning process provided by the teacher.

Then related to the inhibiting factors for implementing online learning, Wati stated that "the solution is to find a place or area with a stable and smooth network. Students with insufficient quota are encouraged to come to school using a computer or Wi-Fi which is available at the school, in compliance with health protocols. In addition, asking students to come directly to the house to take assignments that have been prepared in the form of work sheets can be an alternative way (interview on October $\left.16^{\text {th }}, 2020\right)$. The results of the interview also shows that several solutions are given to make the implementation of online learning run well at SMA Negeri 2 Kuala Kapuas.

\section{CONCLUSION}

Based on the elaboration in the discussion part above, the results of this research analysis can be described as follows.

1. There are three efforts done by Hindu religious education teachers to the implement online learning in the new normal era at SMA Negeri 2 Kuala Kapuas. First, the efforts of Hindu religious education teachers to prepare online learning at SMA Negeri 2 Kuala Kapuas such as preparing interesting learning tools properly. Then they prepare supporting facilities, including computers, laptops and smartphones. In addition, Hindu religion and character textbooks are also prepared. With careful preparation in online learning, it is the effort of Hindu Religion Teachers in preparing online learning. Second, the efforts of Hindu religious teachers to carry out online learning at SMA Negeri 2 Kuala Kapuas. The teachers carry out online learning with face-to-face (physical) learning between teachers and students done online using an internet network. In addition, the implementation of the online learning that is carried out is directed at achieving certain goals that have been formulated using synchronous and asynchronous methods, as well as utilizing learning videos as online learning media. Finally, Hindu religious education teachers' efforts in evaluating online learning process at SMA Negeri 
2 Kuala Kapuas. They have made some efforts to evaluate the implementation of online learning. One way of evaluating online learning is by giving assignments in the form of questions to students.

2. There are also some factors that influence the efforts of Hindu religious education teachers when conducting online learning in the new normal era at SMA Negeri 2 Kuala Kapuas. First of all, supporting factors for online learning are the existence of adequate facilities, a conducive situation, a smooth internet network and a sufficient quota. Then inhibiting factors are a lack of motivation from students, lack of facilities and infrastructure or communication tools owned by students, the distance of the student's residence that is far from the reach of the internet connection. In addition, sometimes students do not have sufficient funds to buy quotas. It is because lack of support from their parents. Inadequate internet access or network at students' houses also affect the process of online learning. Each student also has different technological and economic abilities. It makes the submission of material and the process of monitoring the students' participation not optimal. This is certainly a lesson for the school to improve the quality of online learning at SMA Negeri 2 Kuala Kapuas.

\section{REFERENCES}

Arimbawa, I Gede Arsa, dkk. (2018). Peran Guru Pendidikan Agama Hindu dalam Membangun Nilai Karakter Siswa melalui Implementasi Tri Hita Karana. IVCEJ, Vol 1 No 1.

Gunawan, I. G. D., Suda, I. K., \& Indiani, N. M. (2020). Existence Of Pasraman Gurukula Bangli As A Hindu Educational Institution. Vidyottama Sanatana: International Journal of
Hindu Science and Religious Studies, 4(1), 28-35.

Hiroyuki, A., Juliawan, I. N., \& Sudarsana, I. K. (2018). Internalization Values Of Character Education Towards The Teruna-Daha In The MediMedian Tradition. Vidyottama Sanatana: International Journal of Hindu Science and Religious Studies, 2(2), 232-238.

Kusmijati, N. (2014). Peningkatan Kreativitas Belajar Siswa Pada Mata Pelajaran Ilmu Pengetahuan Sosial Melalui Model Pembelajaran Discovery Learning di SMP Negeri 2 Purwokerto. Geo Edukasi, 3(2).

Lailatussaadah, L., Fitriyawany, F., Erfiati, E., \& Mutia, S. (2020). FaktorFaktor Penunjang Dan Penghambat Dalam Pelaksanaan Pembelajaran Daring (Online) Ppg Dalam Jabatan (Daljab) Pada Guru Perempuan Di Aceh. Gender Equality: International Journal of Child and Gender Studies, 6(2), 41-50.

Pangondian, R. A., Santosa, P. I., \& Nugroho, E. (2019). Faktor-Faktor Yang Mempengaruhi Kesuksesan Pembelajaran Daring Dalam Revolusi Industri 4.0. In Seminar Nasional Teknologi Komputer \& Sains (SAINTEKS) (Vol. 1, No. 1).

Putria, H., Maula, L. H., \& Uswatun, D. A. (2020). Analisis proses pembelajaran dalam jaringan (daring) masa pandemi covid-19 pada guru sekolah dasar. Jurnal Basicedu, 4(4), 861-870.

Sadikin, Ali dan Hamidah, Afreni. (2020). Pembelajaran Daring di Tengah Wabah Covid-19. BIODIK: Jurnal Ilmiah Pendidikan Biologi Vol. 6, Nomor 02.

Sudarsana, I Ketut. (2020). Book Chapter Menyemai Benih Dharma Perspektif Multidisiplin. Talakar: Yayasan Ahmar Cendikia Indonesia.

Sudarsana, I. K., Lestari, N. G. A. M. Y., Wijaya, I. K. W. B., Krisdayanthi, 
A., Andayani, K. Y., Trisnadewi, K., ... \& Aryana, I. M. P. (2020). Covid-

19: Perspektif Pendidikan. Yayasan Kita Menulis.

Sugiyono. (2019). Metode Penelitian dan

Pengembangan. Bandung: Alfabeta. 